\title{
Correlation of feline immunodeficiency virus status and the severity of feline chronic gingivostomatitis
}

\section{Correlação do status sorológico para FIV e a gravidade da gengivoestomatite crônica felina}

\author{
Reginaldo Pereira de SOUSA FILHO ${ }^{1}$; Keytyanne de Oliveira SAMPAIO ${ }^{2}$; Didier Quevedo CAGNINI ${ }^{3}$; Assis \\ Rubens MONTENEGRO ${ }^{1}$; Mariana Araújo ROCHA ${ }^{1}$; Janaina Serra Azul Monteiro EVANGELISTA ${ }^{1}$; Marina \\ Gabriela Monteiro Carvalho Mori da CUNHA ${ }^{4,5}$
}

\author{
${ }^{1}$ Universidade Estadual do Ceará, Faculdade de Medicina Veterinária, Fortaleza - CE, Brazil \\ ${ }^{2}$ Universidade Federal Rural de Pernambuco, Departamento de Medicina Veterinária, Recife - PE, Brazil \\ ${ }^{3}$ Universidade Federal de Goiás, Jataí - GO, Brazil \\ ${ }^{4}$ Katholiek Universiteit Leuven - Leuven, Belgium \\ ${ }^{5}$ Universidade Estadual do Ceará, Departamento de Desenvolvimento e Regeneração, Laboratório de \\ Cirurgia Experimental, Fortaleza - CE, Brazil
}

\begin{abstract}
Feline chronic gingivostomatitis (FCGS) is a challenge for the veterinary practitioner since its etiology and treatments are still undefined. The present paper investigated the role of the feline immunodeficiency virus (FIV) in the severity of the FCGS. Oral mucosal biopsies obtained from 19 cats with FCGS were divided into two groups according to their FIV serology status. Later, the clinical lesion score was correlated with the histopathological grade of FCGS lesions and the degree of immunostaining in both groups. Most of the animals had significant histological changes; however, no correlation with FIV immunostaining intensity was observed. It was concluded that the presence of FIV infection or the animal's seropositivity status does not seem to interfere with the severity of clinical signs nor the degree of histopathological changes when compared to the seronegative group.
\end{abstract}

Keywords: Feline ulcerative stomatitis. Lymphocytic-plasmacytic stomatitis. Glossitis. Inflammation.

\section{Resumo}

A gengivoestomatite crônica felina (FCGS) é um desafio para o veterinário, uma vez que a sua etiologia e tratamentos permanecem indefinidos. O presente trabalho investigou o papel do vírus da imunodeficiência felina (FIV) na gravidade do FCGS. Biópsias da mucosa oral de 19 gatos com FCGS foram divididas em dois grupos de acordo com o status sorológico de FIV. Mais tarde, o escore de lesão clínica foi correlacionado com o grau histopatológico das lesões FCGS e o grau de imunocoloração em ambos os grupos. A maioria dos animais apresentou alterações histológicas significativas, porém não foi observada correlação com a intensidade de imunocoloração para FIV. Concluiu-se que a presença de infecção por FIV ou o estado soropositivo dos animais não parece interferir com a gravidade dos sinais clínicos nem com o grau de alterações histopatológicas quando comparado ao grupo soronegativo.

Palavras-chave: Estomatite ulcerativa felina. Estomatite linfocítica-plasmocítica. Glossite. Inflamação.

Correspondence to:

Reginaldo Pereira de Sousa Filho

Universidade Estadual do Ceará, Faculdade de Medicina

Veterinária

Av. Bernardo Manuel, 8600 - Itaperi

CEP 60761-282, Fortaleza, CE, Brazil

e-mail: reginaldo.filho@uece.br

Received: 03/03/2018

Approved: 07/08/2018

\section{Introduction}

Feline chronic gingivostomatitis (FCGS) or feline chronic lymphocytic plasmacytic stomatitis/gingivitis (ARJONA et al., 2000) is characterized by proliferative and ulcerative lesions in the palatoglossal arch and buccal gingiva, affecting areas such as pharynx, tongue and lips (ARZI et al., 2010). FCGS is a severe, 
idiopathic oral inflammatory disease without a clear effective treatment (ARZI et al., 2016). Thirty percent of the cats will be refractory to the current standard treatment, which is full-mouth or near full-mouth tooth extraction (JENNINGS et al., 2015). FCGS pathogenesis is still not completely understood, but it is thought that the host immune system response is inappropriate to chronic oral antigenic stimulation secondary to underlying oral disease, such as subclinical viral infections (ARZI et al., 2010, 2016) or autoimmune disorders, such as systemic lupus erythematosus and pemphigus (LEE et al., 2010).

Scientific evidence points to several viral agents as possible FCGS etiology, such as Feline Immunodeficiency Virus (FIV), Feline Leukemia Virus (FeLV) (HEALEY et al., 2007; ROLIM et al., 2017); Feline Calicivirus (FCV) and Feline Herpesvirus 1 (FHV-1) (LOMMER; VERSTRAETE, 2003). FIV has been reported to be correlated to FCGS in $15 \%$ of the cases (ROLIM et al., 2017).

FIV is a lentivirus capable of inducing a progressive loss of CD4 + lymphocytes and increased CD8 +, due to its tropism for CD4+ T-cells, B-cells and macrophages. This change allows the occurrence of chronic and recurrent infections due to the acquired immunodeficiency syndrome, characterized by a long incubation period, slow clinical evolution and progressive course (ARJONA et al., 2000). Due to the progressive dysfunction of the immune system in FIV+ cats and the possible common association of the virus with FCGS, the objective of this study was to investigate the role of FIV in the severity of the FCGS.

\section{Materials and Methods}

\section{Animals and clinical examination}

This study was conducted with approval of the Ethical Committee for the Use of Animals, State University of Ceará-Brazil, under the number 0119213/2014. All ethical precepts of animal protection were respected and the owners signed an informed consent. Inclusion criteria included cats affectted by FCGS for at least six months before enrollment. If corticosteroids therapy was prescribed, it had to be discontinued for at least two months prior to the biopsy. Samples were collected from 19 cats routinely examined at Veterinary Hospital Unit of the State University of Ceará. The animals characteristics are: age from two to eight years-old 57.8\% (11/19), animals of mixed breed, 26.3\% Siamese and 18.8\% Persian. Fifty-eight percent (11/19) were males and $42 \%(8 / 19)$ were females. Six cats that died from trauma or received indication of euthanasia were selected to be used as controls. None of the animals presented any chronic or degenerative systemic diseases.

All cats were screened for FIV and FeLV infection by immunochromatographic test. Afterward, the cats were divided into two groups according to the result.

Patients were submitted to anesthesia using intravenous ketamine hydrochloride $(3 \mathrm{mg} / \mathrm{kg})$, midazolam $(0.4 \mathrm{mg} / \mathrm{kg})$ and methadone $(0.3 \mathrm{mg} / \mathrm{kg})$ in order to proceed with a complete oral cavity clinical evaluation and collection of biopsies. First, macroscopic lesions were classified and the animals were sorted according to lesion severity, as follows: grade 0 , lesion absence; grade 1 , hyperemia of palatoglossal arch, without ulceration, bleeding or proliferative lesions; grade 2, hyperemia and proliferation of palatoglossal arch, without ulceration or bleeding; grade 3, hyperemia, proliferation and ulceration of palatoglossal arch, with bleeding induced by mild digital compression; grade 4, hyperemia, proliferation and ulceration of palatoglossal arch with spontaneous bleeding (Figure 1A-D).

An incisional biopsy of oral mucosal lesions was performed using a $4 \mathrm{~mm}$ biopsy punch. Samples were always obtained in the caudal region of the palatoglossal arch. Oral biopsies were fixed in 10\% neutral buffered formalin solution for $24 \mathrm{~h}$ for further histological processing. The sections were made at $3 \mu \mathrm{m}$ thickness and stained with hematoxylin and eosin and toluidine blue. 


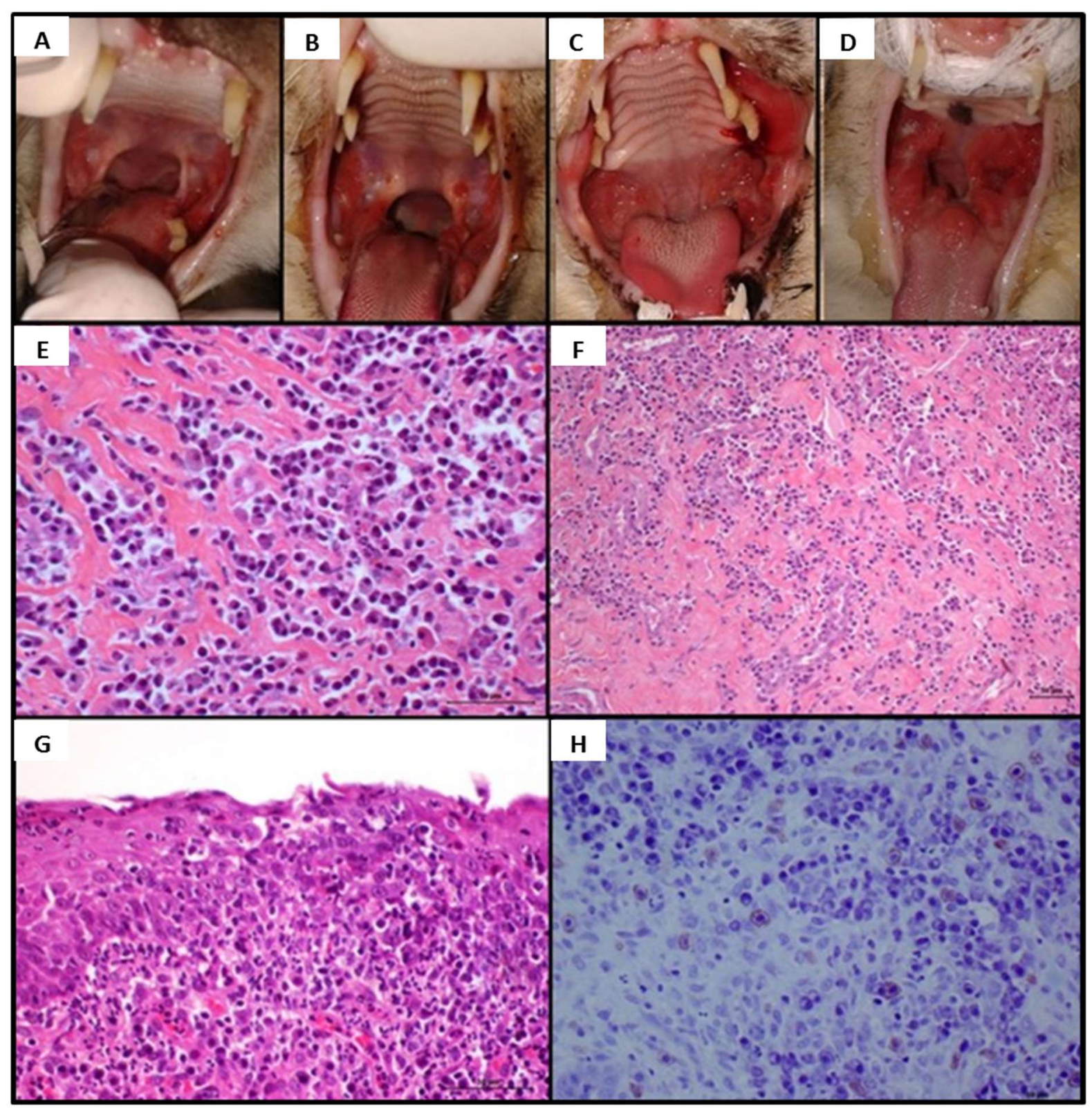

Figure 1 - A) Feline with macroscopic lesion 1 score, palatoglossal hyperemia. B) Feline with score 2 of macroscopic lesion, proliferation of granulomatous tissue in the palatoglossal arch, without ulceration. C) Feline with macroscopic lesion score 3, intense proliferative tissue, with ulceration, but without spontaneous bleeding. D) Feline with macroscopic lesion score 4, granulation tissue, ulceration and spontaneous bleeding. E) Photomicrography of feline FIV positive oral mucosa with FCGS, Mott cells in the submucosa (arrow), HE (40x). Photomicrography of oral mucosa of FIV positive feline with GECF, granulocytic infiltrate (arrow), HE (40x) H) Photomicrography of FIV positive feline oral mucosa with FCGS, presence of mast cells in the submucosa (arrow), AT (20x). Motic ${ }^{\circledR}$ BA310 Trinocular Microscope (Motic ${ }^{\oplus} 2000$ 2.0 MP Live Resolution) and Motic Image Plus 2.0 software 


\section{Immunohistochemical processing}

Immunostainings were performed on $5 \mu \mathrm{m}$ thick paraffin sections. After standard deparaffinization and rehydration procedures, tissue sections were subjected to antigen retrieval by $0.005 \mathrm{M}$ citric acid buffer, heated under constant pressure for $5 \mathrm{~min}$. Endogenous peroxidase activity was blocked by incubating the sections in 6\% hydrogen peroxide in PBS solution for $30 \mathrm{~min}$. The sections were incubated overnight with 1/200 diluted FIV monoclonal primary antibody (PBS, $1 \%$ bovine serum albumin, $0.3 \%$ Tween 20 and $0.1 \%$ sodium azide). Sections were subsequently washed in PBS and incubated with HRP-polymer. Positive areas for FIV were developed after staining with diaminobenzidine solution and counterstaining with Harris hematoxylin. Negative controls were performed with replacement of the primary antibody by deionized water.

\section{Morphometric analysis}

A random quantitative analysis was performed according to the types of inflammatory cells found and later classified on a four-point scale, based on the degree of inflammation, as advocated by Harley et al. (2003), where: $0=$ no inflammation (Normal); $1=$ mild inflammation; 2 = moderate inflammation; 3 = severe inflammation. Further, neutrophils, macrophages, plasma cells, eosinophils, lymphocytes and mast cells were quantitatively analyzed in 10 fields at $400 \mathrm{x}$ magnification for both groups. At least 500 cells were counted using ImageJ digital imager program to conduct a descriptive statistics. The Leica Qwin version 3.0 image analysis program was used in a conventional optical microscope (Leica - DMR, Germany), with a digital coupled camera (Leica DFC500, Germany) for the recording of the photomicrographs.

For immunohistochemistry analysis, 20 random fields of the sample in a 400x magnification were selected for quantification of the stained area. Further, the results were transformed in percentage by the following formula: $(\Sigma(\mathrm{A}) / 20) \times 100$, where (A) corresponds to the area of immunolabelled cells perf field (Motic Image Plus 2.0 software). After that, animals were distributed in degrees of immunoblotting, where: grade 0 , corresponds to the absence of immunostaining; grade 1, weak immunostaining (up to $10 \%$ ); grade 2, moderate immunostaining (from $10.01 \%$ to $50 \%$ ); grade 3 , strong immunostaining (50.01\% to $70 \%$ ); and grade 4 represents an intense immunostaining (above 70.01\%).

\section{Statistical analysis}

Statistical analyses were performed using GraphPad Prism 6 (GraphPad Software, Inc., CA, USA). Results were checked for normality by D'Agostino \& Pearson test. Results were compared using a t-test for parametric results or Mann-Whitney test for non-parametric results. Significance was set at $\mathrm{P}<0.05$. The Pearson correlation coefficient test was used to determine the correlation of clinical classification with histological classification and degree of immunostaining.

\section{Results}

Immunochromatographic tests of 19 cats with FCGS revealed eight FIV positive animals and 11 nonpositive FIV animals. However, two animals of the FIV negative group (animals 4 and 19) had moderate FIVimmunolabeling. A more detailed description of the clinical score, histopathological score and degree of immunostaining is presented in Table 1.

The main clinical signs observed were: palatoglossal hyperemia $(100 \%$; 19/19), enlargement of submandibular lymph nodes (95\%; 18/19), halitosis (90\%; 17/19), dysphagia (90\%; 17/19), pain when the mouth was open $(52 \% ; 10 / 19)$, loss of weight $(52 \% ; 10 / 19)$, anorexia $(45 \% ; 8 / 19)$, oral ulceration $(45 \% ; 8 / 19)$ and dental resorption lesions $(20 \% ; 3 / 19)$. 
Table 1 - Clinical score, degree of histopathological changes and degree of immunostaining in cats with chronic gingivitis stomatitis tested for FIV

\begin{tabular}{ccccc}
\hline Cat & FIV State & Clinical score & $\begin{array}{c}\text { Histopathologic } \\
\text { grade }\end{array}$ & $\begin{array}{c}\text { Immunostaining } \\
\text { degree }\end{array}$ \\
\hline 1 & Negative & 2 & 3 & 0 \\
2 & Positive & 1 & 3 & 2 \\
3 & Positive & 2 & 3 & 3 \\
4 & Negative & 2 & 3 & 2 \\
5 & Positive & 3 & 3 & 4 \\
6 & Negative & 3 & 3 & 0 \\
7 & Negative & 3 & 3 & 0 \\
8 & Negative & 3 & 3 & 0 \\
9 & Negative & 1 & 2 & 0 \\
10 & Negative & 2 & 3 & 0 \\
11 & Negative & 2 & 3 & 2 \\
12 & Positive & 1 & 3 & 2 \\
13 & Positive & 3 & 3 & 1 \\
14 & Positive & 4 & 2 & 4 \\
15 & Positive & 4 & 3 & 2 \\
16 & Positive & 3 & 3 & 0 \\
17 & Negative & 3 & 3 & 0 \\
18 & Negative & 4 & 3 & 3 \\
19 & Negative & 3 & 3 & \\
\hline & & & & 2 \\
\hline
\end{tabular}

In the clinical lesion classification, it was observed that $15.8 \%(3 / 19)$ were grade 1 , while grade 2 was $26.3 \%(5 / 19), 42.1 \%$ grade $3(8 / 19)$ and $15.8 \%(3 / 19)$ grade 4 (Table 1). Histopathological classification showed that $90 \%$ of the cats had lesions grade 3 and $10 \%$ had lesions grade 2 . There was no significant difference in the clinical and histopathological classification and they presented a correlation of 0.9 . Moreover, no differences on the distribution of any grade between FIV positive and FIV negative groups was observed.

The main histopathological changes found in both FIV positive/negative groups were: hyperplasia, parakeratosis, vacuolar degeneration of the epithelium and ulceration. The inflammatory infiltrate composed mainly of plasma cells (Figure 1F), lymphocytes, neutrophils (Figure 1G) and mast cells, affecting the submucosa, perivascular regions and salivary glands. Mott cells (Figure 1E) were found in three animals (two FIV + and one FIV-).
The inflammatory infiltrate in both groups consisted mainly of plasma cells and neutrophils, followed by lymphocytes (Table 2). Neutrophils, lymphocytes, plasmocytes and mast cells were distributed similarly between both groups; however, macrophages were significantly higher in the FIV + group (Figure 2).

In the present study, the presence of mast cells was moderate and observed mainly in the submucosa in 95\% of the animals (Figure $1 \mathrm{H}$ ).

Cytoplasmic immunostaining for FIV was observed mainly in plasma cells, lymphocytes and neutrophils. All FIV + cats had positive immunostaining for FIV. Moreover, two FIV - cats also presented immunostaining for FIV (Grade 2 and 3). Grade 2 immunolabeling was observed in $43 \%$ of the cats (5/11), followed by $18 \%$ of the other grades $(2 / 11)$. No correlation between degree of immunostaining intensity and clinical score of the animal was observed. Considering IHC results, our study presented 52.6\% (10/19) positivity for FIV. 
Table 2 - Quantification of inflammatory infiltrate in the oral mucosa of cats affected by FCGS

\begin{tabular}{cccccc}
\hline Cat & Neutrophils & Plasmocytes & Lymphocytes & Macrophages & Mast cells \\
\hline 1 & $36,9 \%$ & $61,5 \%$ & $1,6 \%$ & $0 \%$ & $0 \%$ \\
2 & 17,0 & 61,5 & 10,6 & 0 & 10,9 \\
3 & 38,0 & 44,0 & 8,0 & 0 & 10,0 \\
4 & 4,0 & 87,6 & 1,9 & 0 & 6,5 \\
5 & 7,9 & 81,0 & 2,5 & 1,5 & 7,1 \\
6 & 24,3 & 70,8 & 0,8 & 0 & 4,1 \\
7 & 27,5 & 65,7 & 1,4 & 0,3 & 5,1 \\
8 & 42,8 & 54,5 & 0,8 & 0 & 1,9 \\
9 & 7,3 & 45,9 & 34,5 & 0 & 12,3 \\
10 & 44,5 & 42,5 & 5,3 & 0 & 7,7 \\
11 & 39,2 & 51,2 & 7,1 & 0 & 2,5 \\
12 & 35,7 & 36,6 & 20,6 & 2,6 & 4,5 \\
13 & 35,0 & 45,0 & 8,0 & 5,0 & 7,0 \\
14 & 37,1 & 37,5 & 12,5 & 3,7 & 9,2 \\
15 & 34,0 & 59,6 & 1,5 & 0,2 & 4,7 \\
16 & 64,4 & 28,4 & 4,9 & 0,3 & 2,0 \\
17 & 12,4 & 62,2 & 20,2 & 0,4 & 4,7 \\
18 & 17,0 & 52,0 & 19,0 & 1,0 & 11,0 \\
19 & 51,0 & 42,0 & 4,0 & 1,0 & 2,0 \\
\hline
\end{tabular}
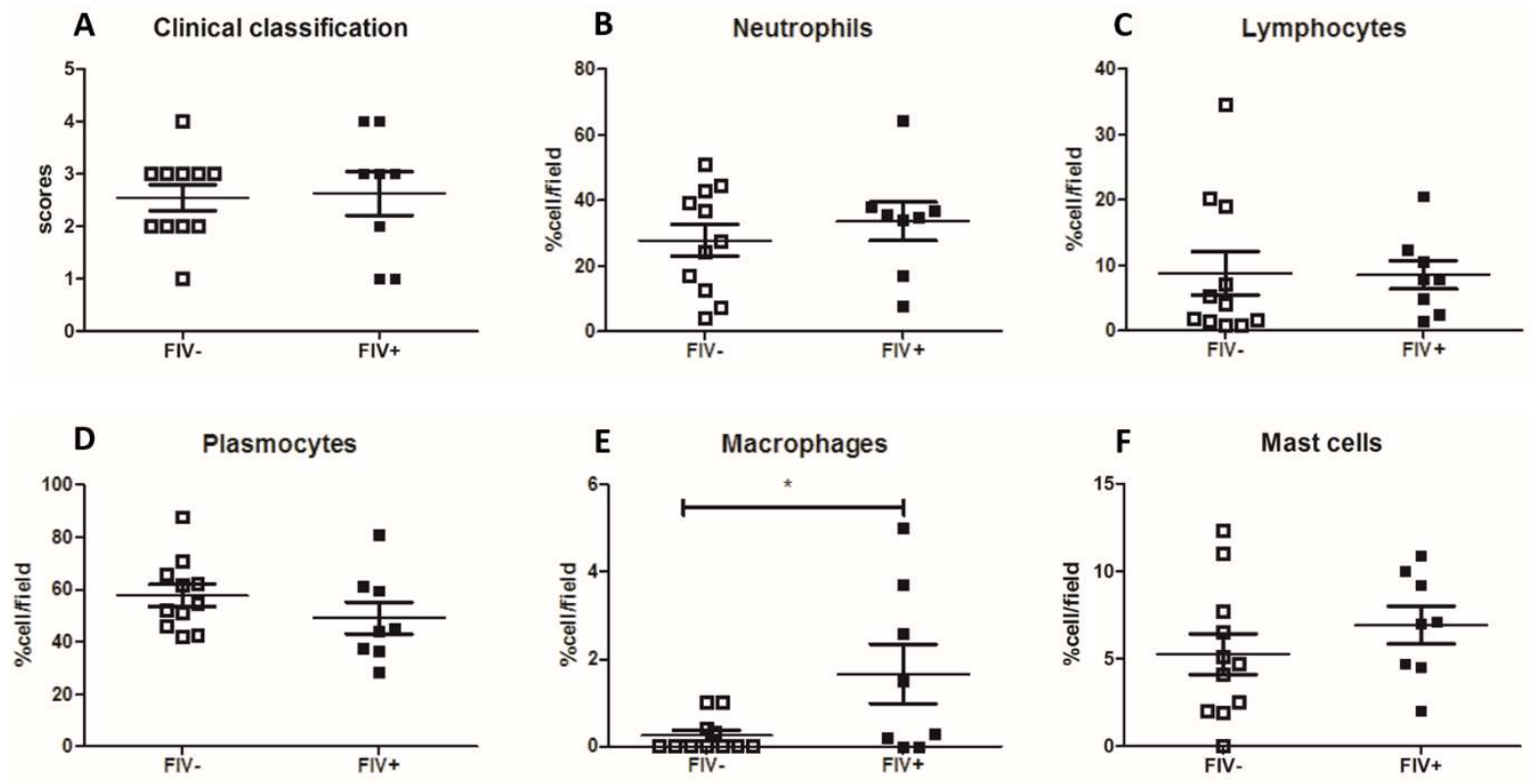

Figure 2 - Clinical classification (A) and quantification of histological staining of neutrophils (B), lymphocytes (C), plasmocytes (D), macrophages (E) and Mast cells (F). Bar heights represent mean values, and brackets indicate SEM. Five fields were counted on two slides of each organ from three mice in each group. FIV + cats showed significant higher amount of macrophages than FIV - cats $(\mathrm{P}<0.05)$

\section{Discussion}

FGCS is a common disease with poorly understood pathogenesis. Several viral agents are thought to play an important role in the disease process. FIV has been reported to be correlated to FCGS in $15 \%$ of the cases (ROLIM et al., 2017). In the current study, no difference in disease severity was found between FIV+ and FIV- groups; however, a significantly higher presence of macrophages was observed in the FIV+ groups.

The higher presence of macrophages in FIVpositive cats can be explained by the role of these cells 
in the pathogenesis of retroviruses. In human immunodeficiency virus type 1 (HIV-1) infection, macrophages play a crucial role in all of its stages. They are important target cells for HIV-1 in vivo, due to few peculiarities which help to perpetuate the virus, such as: slow production and release of infectious HIV-1 and lower sensitivity to viral cytotoxicity compared to CD4 $+\mathrm{T}$ cells, making them more resistant cell (KOPPENSTEINER et al., 2012). Especially longlasting macrophages may harbor the virus for lengthy periods of time leading to viral hideouts during the chronic phase of the infection (KOPPENSTEINER et al., 2012). Therefore, HIV-1 reservoirs have been described as a major obstacle for virus eradication from infected individuals (GENDELMAN et al., 1989). Since macrophages secrete cytokines that recruit $\mathrm{T}$ cells to infection sites, they can support the establishment of viral infection by increasing the number of primary target cells. Thus, a higher viral transmission to $\mathrm{CD} 4+\mathrm{T}$ cells can happen via cell-tocell contact during antigen presentation (KOPPENSTEINER et al., 2012).

Interestingly, the importance of macrophages in the early phase of FIV infection has also been identified. Bingen et al. (2002) highlighted the role played by macrophages in FIV uptake and viral spread when FIV was inoculated in cats. Moreover, they reported that macrophages are the most important target cells by this retrovirus in the early infection phase (BINGEN et al., 2002). Some FIV strains are monocytotropic in vivo, which may be related to viral virulence, vertical transmission and infection of tissues rich in macrophages (DOW et al., 1999).

The histopathological changes observed in this study corroborate with previous publications, which observed a marked infiltration of lymphocytes and plasma cells (HARLEY et al., 2011; ROLIM et al., 2017). On the other hand, a higher number of neutrophils was observed compared to lymphocytes, which diverges from previous report (HARLEY et al., 2011). Even though it is known that FIV causes a decrease in the neutrophil population of the affected feline (YAMAMOTO et al., 2007), the present investigation observed a large number of neutrophils in the mucosa of both groups evaluated in our study. This probably reflects the bacterial component of the etiopathogenesis of FCGS. The presence of several oral bacteria associated with the disease has been previously reported (DOLIESLAGER et al., 2013).

The marked presence of plasma cells in the inflammatory infiltrate, together with the decrease in lymphocytes can be explained by the immunesuppressive action of FIV (MIYAZAWA, 2002). However, in the present study, the same histopathological pattern was observed in seronegative animals. Plasma cells are differentiated B-cells, present in chronic oral inflammations, which have a large capacity to produce immunoglobulins. This can explain the increase in IgG and IgM levels in animals with FCGF (HARLEY et al., 2003). Mott cells are plasmocytes with multiple immunoglobulin vacuoles, mainly IgM. These cells were observed in three cats of the present study, and might be due to the chronic immunostimulation to produce immunoglobulins. These cats had severe histopathological grade of associated periodontal diseases such as dental calculi and lesions of tooth resorption. So, FGCS may present along with periodontal disease, something common in FIV-positive cats (ELDER et al., 2010).

Mast cells are important sentinel cells that participate in mucosal immunity in the acute inflammatory process. Moreover, their involvement has been described in the FGCS (ARZI et al., 2010). The moderated presence of mast cells observed in the present study may be due to the chronic stage of inflammation in the animals investigated.

Two discordant results between immunochromatographic and immunostaining could be due to the false-negative results of immunochromatographic exams, especially at the initial and late stages of infection (HOSIE et al., 2009). This happens since, in the initial stage, the seroconversion has not yet started, while in the late stage, the immunodeficiency has already developed. Both false-negative cats had severe 
cases of gingivitis stomatitis, with a degree of histopathological lesion and high clinical score, which may suggest chronic infection and possibly low availability of antibodies, resulting in false-negative results (HOSIE et al., 2009). No animal was positive for FeLV, which diverged with high prevalence and association with FeLV with FCGS described previously (QUIMBY et al., 2008; ROLIM et al., 2017).

Similar distribution of the cats according to the clinical and histological scores indicates that probably there is no correlation between FIV and severity of lesions. Moreover, there was no observed correlation between degree of immunostaining intensity and clinical score of the animal, possibly demonstrating that degree of viral infection by FIV does not predict severity of the oral disease.

\section{Conclusion}

FIV infection does not seem to interfere with severity of clinical signs or degree of histopathological lesions of FCGS. Histopathological and immunepathogenic analysis of cats at the early stage of FCGS might clarify the association with different etiological agents. This could contribute to the elucidation of the disease etiology, prevention and treatment.

\section{Conflict of interest}

The authors declare that there is no conflict of interest regarding the publication of this paper.

\section{Sources of Acquisition}

A - Anigen Rapid FIV/FeLV Test, Bioeasy, São PauloSP

B - Anti-FIV p24 antibody [PAK3-2C1] ab65289, Abcam, USA

C - Super Picture TM HRP Plymer Conjugate Broad Spectrum-Invitrogen Corporation, Frederick, MD 21704, USA.

major sites of feline immunodeficiency virus uptake after intravenous inoculation into cats. Microbes and Infection, v. 4, n. 8, p. 795-803, 2002. doi: 10.1016/S1286-4579(02)01599-X.

DOLIESLAGER, S. M.; BENNETT, D.; JOHNSTON, N.; RIGGIO, M. P. Novel bacterial phylotypes associated with the healthy feline oral cavity and feline chronic gingivostomatitis. Research in Veterinary Science, v. 94, n. 3, p. 428-432, 2013. doi: 10.1016/j.rvsc.2012.11.003.

DOW, S. W.; MATHIASON, C. K.; HOOVE E. A. In vivo monocyte tropism of pathogenic feline immunodeficiency viruses. Journal of Virology, v. 73, n. 8, p. 6852-6861, 1999.

ELDER J. H.; LIN, Y. C.; FINK, E.; GRANT, C. K. Feline immunodeficiency virus (FIV) as a model for study of lentivirus infections: parallels with HIV. Current HIV Research, v. 8, n. 1, p. 73-80, 2010. doi: 10.2174/157016210790416389.

GENDELMAN, H. E.; ORENSTEIN, J. M.; BACA, L. M.; WEISER, B.; BURGER, H.; KALTER, D. C.; MELTZER, M. $S$. The macrophage in the persistence and pathogenesis of HIV infection. International AIDS Society Journal, v. 3, n. 8, p. 475-496, 1989. 
HARLEY, R.; GRUFFYDD-JONES, T. J.; DAY, M. J. Salivary and serum immunoglobulin levels in cats with chronic gingivostomatitis. Veterinary Record, v. 152, n. 5, p. 125-129, 2003.

HARLEY, R.; GRUFFYDD-JONES, T. J.; DAY, M. J. Immunohistochemical characterization of oral mucosal lesions in cats with chronic gingivostomatitis. Journal of Comparative Pathology, v. 144, n. 4, p. 239-250, 2011. doi: 10.1016/j.jcpa.2010.09.173.

HEALEY, K. A.; DAWSON, S.; BURROW, R.; CRIPPS, P.; GASKELL, C. J.; HART, C. A.; PINCHBECK, G. L.; RADFORD, A. D.; GASKELL, R. M. Prevalence of feline chronic gingivo-stomatitis in first veterinary practice. Journal of Feline Medicine and Surgery, v. 9, n. 5, p. 373381, 2007. doi: 10.1016/j.jfms.2007.03.003.

HOSIE, M. J.; ADDIE, D.; BELAK, S.; BOUCRAUTBARALON, C.; EGBERINK, H.; FRYMUS, T.; GRUFFYDD-JONES, T.; HARTMANN, K.; LLORET, A.; LUTZ, H.; MARSILIO, F.; PENNISI, M. G.; RADFORD, A. D.; THIRY, E.; TRUYEN, U.; HORZINEK, M. C. Feline immunodeficiency. ABCD guidelines on prevention and management. Journal of Feline Medicine and Surgery, v. 11, n. 7, p. 575-584, 2009. doi: 10.1016/j.jfms.2009.05.006.

JENNINGS, M. W.; LEWIS, J. R.; SOLTERO-RIVERA, M. M.; BROWN, D. C.; REITER, A. M. Effect of tooth extraction on stomatitis in cats: 95 cases 2000-2013. Journal of the American Veterinary Medical Association, v. 246, n. 6, p. 654-660, 2015. doi: 10.2460/javma.246.6.654.

KOPPENSTEINER, H.; BRACK-WERNER, R.; SCHINDLER, M. Macrophages and their relevance in Human Immunodeficiency Virus Type I infection. Retrovirology, v. 9, n. 82, p. 1-11, 2012. doi: 10.1186/1742-4690-9-82.
LEE, M.; BOSWARD, K. L.; NORRIS, J. M. Immunohistological evaluation of feline herpesvirus-1 infection in feline eosinophilic dermatoses or stomatitis. Journal of Feline Medicine and Surgery, v. 12, n. 2, p. 7279, 2010. doi: 10.1016/j.jfms.2009.12.013.

LOMMER, M. J.; VERSTRAETE, F. J. M. Concurrent oral shedding of feline calicivirus and herpervirus 1 in cats with chronic gingivostomatitis. Oral Microbiology and Immunology, v. 18, n. 2, p. 131-134, 2003. doi: 10.1034/j.1399-302X.2003.00033.x.

MIYAZAWA, T. Infections of feline leukaemia virus and feline immunodeficiency virus. Frontiers in Bioscience, v. 7, p. 504-518, 2002.

QUIMBY, J. M.; ELSTON, T.; HAWLEY, J.; BREWER, M.; MILLER, A.; LAPPIN, M. R. Evaluation of the association of Bartonella species, feline herpesvirus 1, feline calicivirus, feline leukemia virus and feline immunodeficiency virus with chronic feline gingivostomatitis. Journal of Feline Medicine and Surgery, v. 10, n. 1, p. 66-72, 2008. doi: 10.1016/j.jfms.2007.05.007.

ROLIM, V. M.; PAVARINI, S. P.; CAMPOS, F. S.; PIGNONE, V.; FARACO, C.; MUCCILLO, M. S.; ROEHE, P. M.; DA COSTA, F. V.; DRIEMEIER, D. Clinical, pathological, immunohistochemical and molecular characterization of feline chronic gingivostomatitis. Journal of Feline Medicine and Surgery, v. 19, n. 4, p. 403 409, 2017. doi: 10.1177/1098612X16628578.

YAMAMOTO, J. K.; PU, R.; SATO, E.; HOHDATSU, T. Feline immunodeficiency virus pathogenesis and development of a dual-subtype feline-immunodeficiencyvirus vaccine. AIDS, v. 21, n. 5, p. 547-563, 2007. doi: 10.1097/QAD.0b013e328013d88a. 